\title{
Urban agriculture in Havana - evidence from empirical research
}

\begin{abstract}
The aim of this article is to indicate the features of contemporary urban agriculture present in the contiguously built-up areas of Havana. Using an exploratory and classification approach, the authors draw on fieldwork and a prior analysis of satellite and aerial imagery, first to characterize the spatial distribution of urban gardens and then to point to their main intrinsic features, including the methods and organization of production and the functions performed. The research conducted shows that urban agriculture is distributed across the city in an uneven fashion, with the main concentration in districts of lower-density urban construction, which reflects the availability of land resources intentionally left between buildings by modernist planners. The most common production technique applied is organopónico, or organoponics. However, the material commonly used to construct the bordering walls is asbestos, which may pose a significant threat for both producers and consumers. Two case studies are analyzed to exemplify different approaches to organic food production.
\end{abstract}

Keywords

Urban agriculture $\bullet$ organic farming $\bullet$ sustainable agriculture $\bullet$ Havana $\bullet$ Cuba

(c) University of Warsaw - Faculty of Geography and Regional Studies
Ada Górna $\mathbb{C}^{1}$,

Krzysztof Górny $\mathbb{\mathbb { C }}^{2}$

${ }^{1}$ Faculty of Geography and Regional Studies University of Warsaw, Warsaw, Poland e-mail: ada.gorna@uw.edu.pl

${ }^{2}$ Faculty of Geography and Regional Studies, University of Warsaw, Warsaw, Poland e-mail: krzysztofgorny@uw.edu.pl
Introduction

In an era of urban civilization, in which more than $50 \%$ of the global population is comprised of city dwellers (UNFPA 2007), an important question arises as to how cities will not only feed themselves but also provide their inhabitants with appropriate and healthy food, while simultaneously enhancing self-sufficiency, sustainability and resilience. Concerns about the food security of urban dwellers have led to a greater interest in food being grown locally within cities (Guitart, Pickering \& Byrne 2012). The definition of urban agriculture might readily be simplified to the one adopted by H. De Bon, L. Parrot and P. Moustier (2010, p. 21): "the growing of plants and the raising of animals for food and other uses within and around cities and towns'. However, some authors elect to expand this basic definition, arguing for the broad conceptualization as an industry in which the production is accompanied by both the processing and the marketing of food (Górna 2018; Orsini et al. 2013; Smit \& Nasr 1992; Smit, Nasr \& Ratta 2001; Van Veenhuizen 2014). In discussing urban agriculture in the context of sustainable development, it is also worth mentioning its multifunctionality and its integration into the urban socio-economic and ecological system (Aubry et al. 2012; Mougeot 2000; Sroka 2014). After all, use is being made of urban resources (land, water and waste) as inputs, land is being competed for, and urban residents are being supplied with both food and employment (De Zeeuw, Van Veenhuizen \& Dubbeling 2011).

Havana, the capital of Cuba and one of the largest Caribbean cities, is regarded as one of the outstanding examples of how urban agriculture may develop. Because of the abundance of urban gardens, as well as the significant role these play in the urban ecosystem, Havana can justifiably serve as the most representative research object anywhere, offering an opportunity for the examination of an alternative organic food provisioning system that has emerged within the borders of a city (Chaplowe 1998; Premat 2005). Many authors have taken up the subject of urban agriculture in Cuba over the past couple of decades, focusing on: its spread since the early 1990s and its contribution to food security and sovereignty of urban dwellers (Altieri et al. 1999; Buchmann 2009; Cruz, Medina 2003; Febles-González et al. 2011; Koont 2011; Leitgeb, Schneider \& Vogl 2016; Murphy 1999; Novo, Murphy 2000; Wright 2012); production methods and forms of organization (Altieri et al. 1999; Chaplowe 1998; Herrera Sorzano 2009; Koont 2009; Murphy 1999); small-scale urban gardens and their social impact (Buchmann 2009; Premat 2005, 2009); and the concepts of metabolic rift and metabolic restoration (Clausen, Clark \& Longo 2015). Some literature examples are based on empirical research, focusing on Havana (Chaplowe 1998; Leitgeb, Schneider \& Vogl 2016; Premat 2005, 2009); particular parts of Havana such as the Consejo Popular Camilo Cienfuegos and the Parque Metropolitano de La Habana (Cruz, Medina 2003); San José de las Lajas (Nelson et al. 2009); or other cities such as Trinidad de Cuba (Buchmann 2009), Pinar del Río and Matanzas (Koont 2011). There are also review articles that include Cuba in their examples (Hallett et al. 2016; Hamilton et al. 2014).

In this article we draw on fieldwork conducted in Cuba's capital in 2018. Based on a sample of 43 study sites we aim to 
point out the features of contemporary urban agriculture present in the contiguously built-up areas of Havana. Using classification and an exploratory approach, we first analyze the location and spatial distribution of urban agriculture sites - rarely discussed in the literature on the topic (the following authors point out some features of the location of urban gardens in Havana: Premat 2005; Viljoen, Howe 2005) - and their intrinsic features: methods of production, organization of production (including distribution), and functions performed. This article also includes an estimation of the total area of the gardens, their average size and the percentage of the area allocated for production in 2018. We focus on medium-size and large urban gardens and exclude the smallest home gardens, although they are the most numerous.

The paper is based on empirical research, which will add to the general knowledge of urban agriculture in Havana, as it draws on specific examples of gardens currently operating in the city. Furthermore, it includes two case studies differing in terms of the intrinsic features analyzed and presenting contrasting approaches to organic and sustainable production techniques and food management, as well as the different roles that they play in Havana's food provisioning system. The two cases are also accompanied by accurate schemas showing the spatial organization of each site.

Towards institutionalization - the origins of urban agriculture in Cuba

Urban agriculture in Cuba dates back to the fall of the Soviet Bloc and the subsequent cessation - in the early 1990s - of the financial and logistical support on which not only the agricultural sector but the entire Cuban economy was dependent (Altieri et al. 1999; Buchmann 2009; Chaplowe 1998). Due to severe food shortages - caused by the significant limitation of trade with its largest economic partner, the USSR, as well as a trade embargo imposed by the USA, Cuba's closest and economically most powerful neighbour - Cubans were forced to apply a different food provisioning strategy that would make the cities more selfsufficient. An overriding goal was also to ensure food security for those particularly in need.

In 1990, the Cuban government officially proclaimed the Special Period in Time of Peace (El período especial en tiempos de paz) that comprised a large-scale austerity programme and strict rationing of resources (Altieri et al. 1999; Buchmann 2009; Nelson et al. 2009). One of the state's priorities, aimed at mitigating the ravages of the economic crisis, was to develop a more sustainable agricultural model that would embrace the principles of organic farming (Nelson et al. 2009). Although the urban agriculture movement, almost non-existent in Cuba before 1989 , was at first a spontaneous and grassroots initiative led by groups inexperienced in farming techniques, it was later subject to rapid institutionalization (Altieri et al. 1999; Murphy 1999). In 1993 the Cuban government enforced a new agrarian reform, whereby most of the large state farms were divided up into small collectives in usufruct to workers and termed Basic Units of Cooperative Production (Unidades Básicas de Producción Cooperativa UBPCs) (Buchmann 2009; Murphy 1999; Novo and Murphy 2000).

A critical moment in Cuban urban agricultural history then came with the establishment of the Urban Agriculture Department within the Ministry of Agriculture (MINAGRI) in 1994 (Altieri et al. 1999; Novo and Murphy 2000). The main objective was the provisioning of unused land for those wishing to cultivate it and produce food in the city. In this context, residents keen on starting an urban garden were able to request the relevant rights to use the land.

Urban agriculture in Cuba is currently organized at the national and municipal levels, within different cooperative, state and private structures, and various subprogrammes involving production, livestock and supporting services (Herrera 2009; Novo and Murphy 2000). It is not only highly institutionalized but also under strict control in terms of both the supply of inputs and organic farming practices (Nelson et al. 2009). The government support and reform led to an increase in the number of urban gardens located on previously abandoned, unused and neglected land in Havana and other Cuban cities, while strict control over farm practices has ensured and enhanced the implementation of organic production methods (Altieri et al. 1999; Nelson et al. 2009). The gardens are coordinated by the National Urban Agriculture Group (Grupo Nacional de Agricultura Urbana - GNAU) consisting of producers, specialists, civil servants and scientific and production institutions (Febles-González et al. 2011).

Types of urban agriculture - critical appraisal of the literature

There are several authors who discuss types of urban agriculture in Cuba (Altieri et al. 1999; Díaz \& Harris 2005; Herrera Sorzano 2009; Koont 2009; Murphy 1999; Novo \& Murphy 2000). They refer to different features of urban gardens, such as cultivation methods, organization of production, or management levels. The following types are discussed most frequently: organopónicos, intensive gardens, and autoconsumos estatales.

Because of the poor anthrosol quality and its contamination with chemicals and building materials such as shards of glass and pieces of concrete and plastic, many urban areas in Cuba are actually unsuitable for cultivation. For that reason, Cuba's city dwellers have developed - and over time disseminated very widely - an organic method of cultivation called organopónico (or organoponics) that is carried out in raised container beds. These so-called canteros are filled with a soil mix that has a high compost ratio (Altieri et al. 1999; Murphy 1999) and, because of this method, vacant plots that would be otherwise uncultivable on account of the poor anthrosol quality have been utilized (Murphy 1999). The second type of urban agriculture is the 'intensive garden' type (huerto intensivo). The main difference between such an entity and organopónico is that the plants are grown directly in the ground (Altieri et al. 1999; Koont 2009). Both organopónicos and intensive gardens can be run by private individuals or state institutions (Murphy 1999). Another type referred to in the literature is the autoconsumos estatales, simply known as autoconsumos (sometimes called factory gardens or self-provisioning gardens) (Altieri et al. 1999; Murphy 1999), which use produce to supply cafeterias and canteens for particular workplaces, for example a factory, a state institution, a military office, a hospital, a school or a nursing home (Murphy 1999). In many autoconsumos, the produce is first destined for selfprovision, with the second option being direct sales to workers or the local population (Novo and Murphy 2000). The connections with local food markets may thus vary depending on the share of the produce intended for sale.

Other types or forms of urban agriculture occurring in the literature are, for example, popular gardens, household gardens, hydroponics, suburban farms or parcels and patios (Altieri et al. 1999; Herrera Sorzano 2009; Murphy 1999).

The above categorization, while it includes most of the common forms of urban gardens in Cuba, is not in fact comprehensive, and might also be seen as somewhat unclear. After all, the types presented overlap and are complementary, while the terminology at times refers to production methods and other times to the ways in which production and distribution are organized. For example, organopónico is an agricultural production strategy, rather than an organizational category (Murphy 1999). Moreover, both organopónicos and intensive gardens utilize intensive and organic production methods, and cultivation is even carried out in raised beds. The only difference is the presence of containers or other forms of bordering walls. 
Furthermore, autoconsumos, that clearly refer to the organization of production and the destination of produce, might employ both organoponic techniques and methods in which plants are grown directly in the ground. Thus, to avoid any confusion or misclassification of particular sites, this article will use the terms organopónico and intensive garden to describe methods or production techniques, while using autoconsumo to refer to the organization of production.

Contemporary urban agriculture - evidence from empirical research

Research methodology and its accuracy

This research has been conducted using mainly qualitative methods, in particular an exploratory and classification approach. It has been divided into two main stages. The first was based on the analysis of high-resolution Google Earth Pro images, providing for the mapping of urban agriculture sites in the research area, while the second comprises fieldwork carried out to verify the prior spatial analysis and provide information on intrinsic features (methods of production, organization of production and functions performed) of each site visited. Both stages will be analyzed further.

As urban agriculture involves an abundance of different crops planted next to one another and employs multiseasonal cropping, the structures of urban gardens are highly diversified. Furthermore, a particularly typical feature of Havana's organopónicos is that a crop might be maturing in one raised bed at the same time as the same crop is being planted in the neighbouring or even the same one (Forster, Buehler \& Kellenberger 2009). Such attributes of urban agriculture constitute a major challenge to the application of remote sensing methods in analysis. Reference to the results of research conducted by other authors in Hanoi (Forster, Buehler \& Kellenberger 2009) and Chicago (Taylor \& Lovell 2012) ensured the selection of a manual interpretation approach to the high spatial resolution images available from the Google Earth Pro freeware program. This mapping approach, though more time-consuming, has proved suitable in the face of the marked heterogeneity of vegetation cover at the production sites analyzed. However, aware of the limitations resulting from the use of the satellite and aerial imagery analysis method for the location of home gardens covering small areas (for example located on patios or balconies), we focus only on medium-size and large gardens. The analysis of such gardens is also more justified in the case of this article, as due to the higher scale of production and the engagement of a larger number of people, they play a more conspicuous and more easily determinable role in the city's food provisioning system as well as its spatial and functional structure.

Since the emphasis of this article is on the urban gardens present in the contiguously built-up areas of Havana, analysis is here limited to a research area that has been arbitrarily designated. Delimitation is based on the manual classification of Google Earth Pro 2017 satellite and aerial imagery, with the relevant part of Havana being of high-density urban construction over an area of $76.7 \mathrm{~km}^{2}$ (Fig. 1). Within the research area, a total of 55 agriculture sites were classified with reference to the satellite and aerial imagery. The margin of error was set at $5 \%$. In the course of the fieldwork carried out in May 2018, 50 of the sites previously classified were actually visited (the remaining five were located in a closed military area or not visible from public land). Some 43 sites were classified as being allocated to urban agriculture (and under current cultivation), and it was those sites that were made subject to further detailed analysis. The remaining seven were either abandoned and not operating at present (five sites) or misclassified as being in agricultural production (two sites, i.e. $4 \%$ of the total sites visited, and so below the margin of error set at $5 \%$ ).

In the course of the fieldwork, 21 semi-structured interviews were conducted. The method of semi-structured interviews was also successfully used by Leitgeb, Schneider and Vogl during their research, conducted in 2012 to 2013 , concerning the impact of state reforms on the food sovereignty of Havana's residents (2016). The group of respondents thus comprised employees working on a field, at a point of sale or in a market, and site bosses. The questions asked concerned the general functioning of the plot and the answers provided information that could not be obtained solely as a result of observation; for example, the number of employees, the full list of plants grown or the place of compost production. Due to the fact that the interviewees were able to introduce different topics, the range of information gathered was usually much wider, and went beyond issues selected previously, which was a significant contribution to the case studies presented. The interviews were not recorded, as per the respondents' wishes. The answers were uploaded into electronic form. Information obtained during the interviews and the accompanying field observations enabled the intrinsic features of each of the gardens to be indicated.

\section{Spatial distribution of urban gardens}

The 43 urban agriculture sites studied were located in the following parts of Havana: Playa (13), Cerro (9), Plaza de la Revolución (8), Diez de Octubre (5), Centro Habana (4), San Miguel del Padrón (2), Habana Vieja (1) and Marianao (1). These gardens are not distributed equally across the research area (Fig. 1), but agriculture is concentrated in several areas. There are 13 sites located within a $1.5 \mathrm{~km}$ radius of the Plaza de la Revolución and seven sites within $1.5 \mathrm{~km}$ of Aerodromo Ciudad Libertad. Eight sites are situated along the coast in the Miramar district. Furthermore, several sites in the south and south-eastern parts of the city occupy areas near municipal green space. The environs of Plaza de la Revolución are considered a civic centre and one of the most representative parts of Havana and yet a considerable proportion of this land is allocated to urban agriculture.

In the most densely urbanized areas like the Vedado, Centro Suárez and Buenavista districts, as well as the area to the north of Centro Habana, no medium-size or large urban agriculture sites were identified, which is consistent with research carried out by Premat (2005), who states that only small-scale urban agriculture sites are present in the most central of Havana's municipalities. The small number of medium-size and large gardens in densely urbanized districts results from the scarcity of available land. According to A. Viljoen \& J. Howe (2005), as the density of inhabitation increases in Havana, intra-urban agriculture diminishes. In contrast, the areas with a high concentration of gardens (especially in the vicinity of the Plaza de la Revolución and Aerodromo Ciudad Libertad) are less densely built-up. Such a spatial distribution of urban agriculture might therefore reflect the urban character of Havana. On the one hand, the city has a compact historical core typical of centres planned during the colonial period. For military and economic reasons these were densely built-up. On the other hand, Havana has less dense, dispersed edges (A. Viljoen \& J. Howe 2005) developing alongside main routes leading towards the city periphery. Within the research area, urban agriculture tends to be concentrated in close proximity to principal arteries, such as Avenida de la Independencia, Avenida 5ta, Avenida 41 and Calzada del Cerro, or on the edges of the areas near municipal green space, in industrial areas or in new residential neighbourhoods, where the availability of land resources is relatively high. A. Premat (2005, p. 161) states that, apart from the outskirts of Havana, organopónicos 


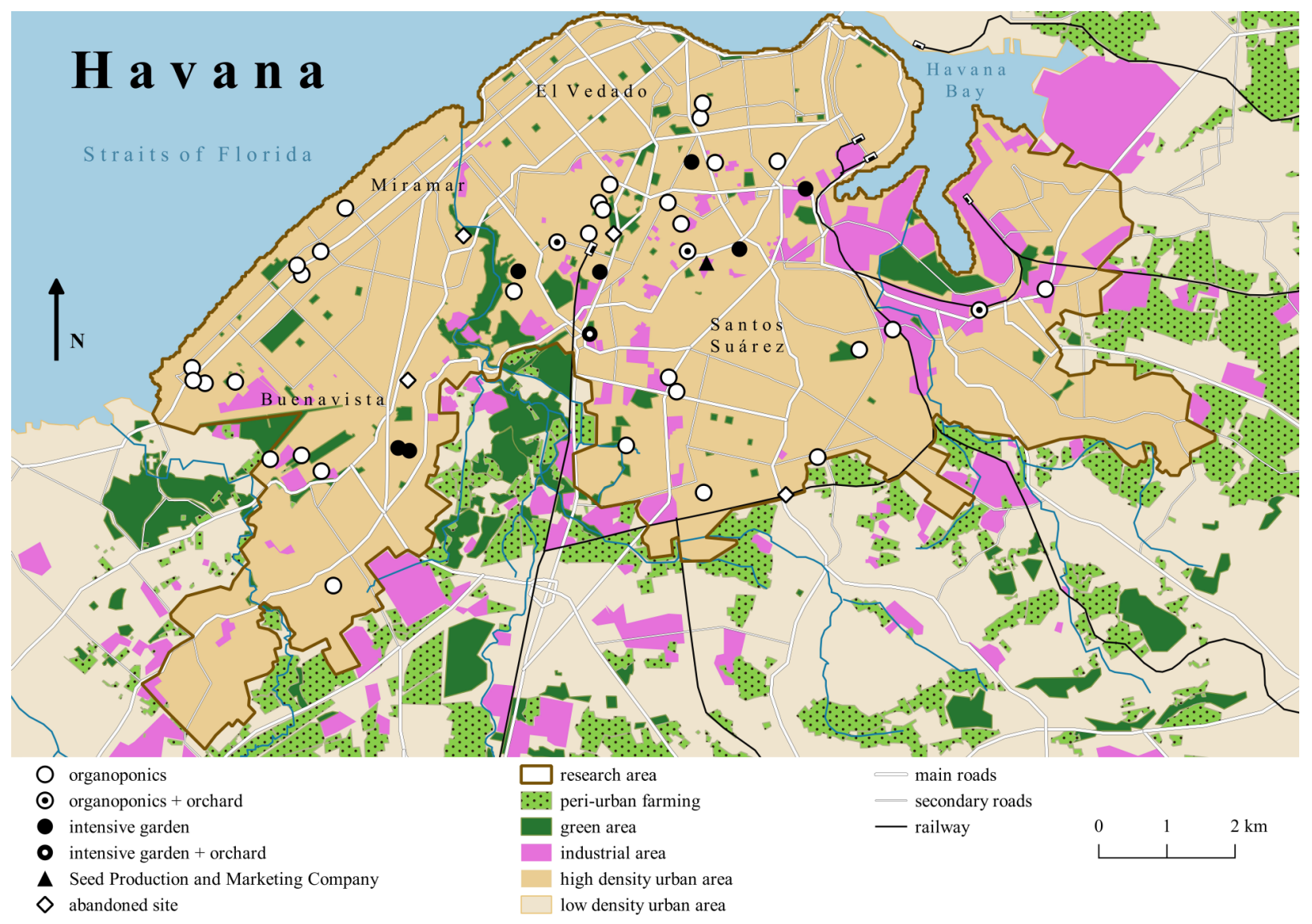

Figure 1. Location of urban gardens within the research area Source: own elaboration on the basis of fieldwork undertaken in 2018

tended to be located in areas of low urban density. This has also been confirmed based on this article's study sample. A. Viljoen and J. Howe (2005) argue that towards the city edges, where the urban area is less compact, the area devoted to urban agriculture plots is greater. However, these conclusions do not apply in the case of this article which focuses mainly on the contiguously built-up areas. In fact, some of the largest gardens are located in the area of the civic centre next to Plaza de la Revolución. The high level of availability of land resources is the direct outcome of modernist urban planning, which meant that extensive green areas were intentionally left between buildings and these were frequently occupied by urban agriculture and continue as such to the present day.

The different historical models of urban planning, both colonial and modernist, that formed Havana's urban space have indirectly influenced the arrangement of today's urban agriculture across the city. The uneven spatial distribution of the food production and provision sites has grave consequences for the food security of the local population. The number of such sites in areas with high population densities is insufficient, and unable to meet demand. For this reason, many residents of such areas, especially in Centro Habana and Habana Vieja, are forced to visit other neighbourhoods in order to buy basic food products (Murphy 1999).

Main features of urban gardens

The total area of all plots visited was $323,035 \mathrm{~m}^{2}$, while the total production area was $152,090 \mathrm{~m}^{2}$. The uncultivated land was usually reserved for additional facilities like seed nurseries, points of sale, markets, tool storage or composting, or else it was simply left unused. The areas of the different sites ranged between $290 \mathrm{~m}^{2}$ and $95,425 \mathrm{~m}^{2}$, while the average area was $7,512.44 \mathrm{~m}^{2}$. The largest production area was $73,448 \mathrm{~m}^{2}$, while the smallest covered just $96.8 \mathrm{~m}^{2}$. The average production area was $3,621.21 \mathrm{~m}^{2}$. The area allocated for production accounted for an average of $41.8 \%$ of the total garden area, the highest share being $77.7 \%$ and the lowest $5.9 \%$.

The most common production technique identified during the fieldwork was organopónico. This is a finding consistent with those of earlier studies and the subject literature (Altieri et al. 1999; Díaz \& Harris 2005). A total of 34 sites (79.1\% of all the urban gardens) applied this method. Raised container beds arranged in characteristic rows were constructed with different kinds of accessible materials. Some sites used medium-size rocks, roof tiles or concrete blocks. However, the prevailing material observed during fieldwork was asbestos. It was observed at 26 of the sites visited (76.5\% of the organopónicos). Raised beds were constructed with fragmented asbestos sheets, both corrugated and flat, as well as asbestos pipes. Due to the resistance this material shows to heat, moisture and acid chemicals, it was increasingly used in house construction following World War II. Once asbestos had been proved to be dangerous, production was banned or restricted in European and North American countries, but it began to be exported to other regions at that time, such as Latin America (Epelman 1993). By the end of the Cold War, one of its largest producers was the Soviet Union (Epelman 1993), hence 
its very popular use in Cuba in the context of Cuba's cooperation within the communist bloc. Although the use of asbestos in urban gardens in Havana has been mentioned in the scientific literature (Cruz, Medina 2003; Hallett et al. 2016), its ubiquity, somewhat alarming given the possible health implications for both producers and consumers (Epelman 1993; Tweedale \& McCulloch 2004), has not been previously supported by quantitative data.

Another form observed in eight plots was the cultivation of plants directly in the ground (in 'intensive gardens', according to the classification discussed above). However, this form was much less frequent, possibly on account of the poor quality of the topsoil in Havana. Only four orchards were observed, though these did not occur individually but were rather elements of sites of other types. Among the plots visited, there was also a Seed Production and Marketing Company (Empresa Productora y Comercializadora de Semillas). Though cultivation was not its main activity, this site did include a small cultivated plot of $677 \mathrm{~m}^{2}$ within its boundaries.

The main plants grown on the sites examined were vegetables (lettuce, onions, spinach, tomatoes), fruit trees (mangoes, papayas) and herbs (basil, oregano, spearmint). The most crucial - and typical - observation of urban agriculture (Smit, Nasr \& Ratta 2001) that all the sites visited featured multiple cropping. Such a practice allowed for the regular provision of varied produce, and also served as a pest control method. Many gardens also employed semi-protected cultivation, which refers to beds being surmounted by shade cloths that were permeable to rain but protected against excess sunlight (Koont 2009).

Twelve sites involved animal husbandry to complement the cultivation of plants. The most common livestock were poultry (observed at 10 sites). Hens roamed free outdoors or were kept in small, vertically arranged cages to limit the space they occupied. Other animals found were goats, rabbits and pigs. The latter are rarely raised in the city centre, as legal regulations ensure that piggeries are located on the fringes of the city at a safe distance from residential areas to reduce the risk of water supplies being contaminated (Novo \& Murphy 2000).

As the use of chemical fertilizers is prohibited within the city limits (Altieri et al. 1999; Novo \& Murphy 2000), urban gardeners used animal and organic household waste, as well as plant residues, to enhance soil fertility. Compost, as an important sustainable agricultural element, was found at 23 sites (53.5\% of all sites). While a majority of organopónicos obtained their compost from rural areas, according to C. Murphy (1999), most of the respondents we spoke to, who confirmed that they used compost, went on to claim that it was generated locally (15 out of 21 interviews). Therefore, it may be the case that, over a period of almost 20 years, gardeners supported by the state had enhanced their capacity to produce compost on site. As for pest control, allelopathic plants were employed instead of synthetic chemical pesticides. The one used in 15 of the organopónicos was Tagetes, which was usually grown on the edge of a bed or in its immediate vicinity.

Eight gardens had their own seed nurseries. The presence of such a facility allowed for the self-supply of seeds and seedlings, with this only adding to the self-sufficiency of a site, and decreasing dependency on seed market prices. Where irrigation was concerned, 11 sites used simple drip watering systems, while the remainder relied on manual watering. Production was not mechanized on any of the sites; they functioned instead using human labour. The tools employed were rather simple and easily maintained. The use of locally produced inputs (like organic matter or seeds) and inexpensive equipment (often made of reused materials) led to a reduction in production costs, and a reduction in the gardeners' reliance on changeable economic conditions that ultimately made the gardens more resilient and sustainable.
Another feature worth considering is the system of organization and the destinations to which produce from each site was sent. Field observation proved that in the case of 19 of the gardens visited $(43.2 \%)$ the produce was intended for sale to the local population (information confirmed by 12 respondents), as well as to restaurants, hotels or diplomatic missions (information confirmed by three respondents). The products could be purchased at small points of sale (puntos de venta) or at the market (agromercado) adjoining the plot. It is worth mentioning that some markets offered locally produced food, whereas others, apart from fruit and vegetables grown on the site, also sold those imported from rural areas. It therefore seems that urban agriculture alone cannot satisfy the demand for agricultural produce and, although urban agriculture is a substantial element of Havana's local food system, it needs to be supported by rural agriculture. The produce from 14 sites, which might be classified as autoconsumos, was intended exclusively for the consumption of the state institutions and was not available at the local market as there was no point of sale or market visible in or near the gardens (information was also confirmed by eight respondents). In the case of 10 gardens, it was impossible to indicate the destination of the produce due to the absence of an interview and the lack of a visible point of sale or market.

The gardens examined were also linked to the local labour market, as they frequently offered employment opportunities for urban dwellers. The number of employees ranged from one to 16 people and the average number was 4.32 . These people worked either on a plot or at a point of sale. However, only 15 out of 21 respondents were authorized or eager to provide information regarding the number of employees.

Many of the gardens analyzed not only employed different production systems but also achieved multifunctionality. They incorporated commodities into the local food market (at the same time contributing to the food security of the inhabitants), offered employment, used urban wasteland, and performed different social functions. Four respondents confirmed that the produce from the gardens in which they worked was directed to nearby schools and the students were also encouraged to participate in the operation of the site in order to learn the principles of organic production. One garden (UCPEJV Organopónico Dirección Producción VRES) was part of a rehabilitation project for what the respondent (project coordinator) referred to as 'troubled youth' (jovenes problematicos). Furthermore, two of the sites visited contributed to scientific research into medicine production (information confirmed by two respondents).

\section{Case studies}

The following case studies exemplify distinct approaches to food production, both in terms of methods applied and organization of production. They perform diverse functions and connect to differing extents with Havana's food provisioning system. The accompanying schemas accurately present the spatial arrangement of all the facilities within the gardens.

\section{Case study 1: La Ceiba Proyecto Comnit. Agroecológico}

La Ceiba is a garden located in an industrial part of the Habana Vieja municipality. It is surrounded by low residential and industrial buildings. The interview was conducted in the garden with the boss, who had been a Physics teacher by profession but had decided to retrain and work on the site. As reported by the respondent, before the garden was created, the lot had been abandoned and had served as a rather spontaneous garbage dump. The land in question was state-owned, and the project gained the support of the Ministry of Agriculture. The site covered 2,985 $\mathrm{m}^{2}$ but with just $1,490 \mathrm{~m}^{2}(49.9 \%)$ involved in production. The plants were grown directly in the ground (it 
was possible to classify the site as an intensive garden), and the entire plot was multiple cropped (Fig. 2). The production was arranged into sections of vegetables and fruit, ornamental plants, aquaculture and animal husbandry (Fig. 3). At the back of the site, next to cages holding hens and rabbits, there was a composter that had been built using concrete blocks. The garden used manual irrigation and natural pest control methods, as, like many other sites visited, Tagetes was used to repel insects. Seeds and seedlings were produced locally in the seed nursery.

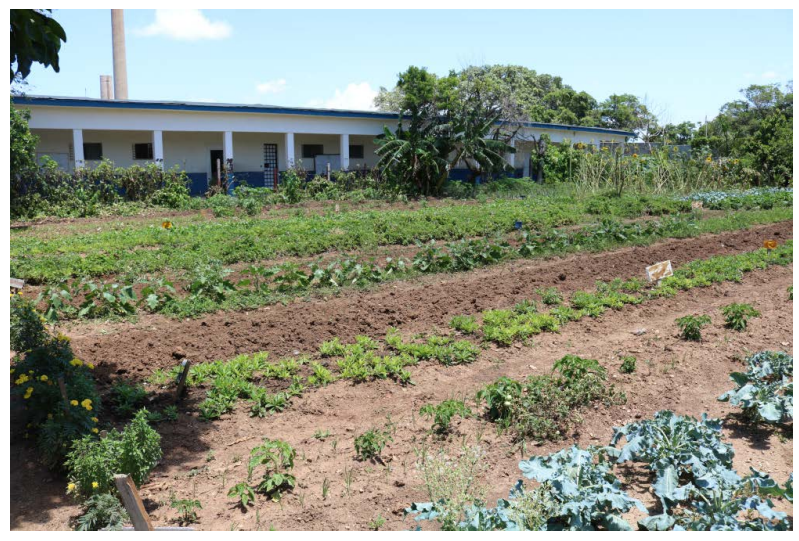

Figure 2. Cultivation at La Ceiba garden Source: photo taken by Krzysztof Górny
Interestingly, despite the site's location next to a school, the former did not support the latter, and all produce it did supply was intended for sale. The point of sale was situated at the front of the lot and was publicly accessible. According to the respondent, the prices were much lower than those in organopónicos in central parts of the city, so that the produce was accessible for the population living nearby. Apart from the boss, six people were employed there, two responsible for fruit and vegetables, three for ornamental plants and one for animals. All of the employees lived nearby. An important feature of the site was that, besides agricultural production, it also had a social and cultural function. Within its boundaries there was a cafeteria, which was also a meeting place for local people and, according to the respondent, enhanced community-building.

\section{Case study 2: the 'Santovenia' Organopónico}

Organopónico 'Santovenia' is located on the Calzada del Cerro, one of the largest arteries of the Cerro municipality. It adjoins a nursing home, Asilo de ancianos Santovenia, run by the convent of the Little Sisters of the Abandoned Elderly (Hermanitas de los Ancianos Desamparados) and it might be considered an autoconsumo. The interview was conducted with an employee working out in the field. The land is state-owned, leased by the convent. As with La Ceiba, this land was unused before the garden was established.

The site was divided into two separate plots by an internal road. One was a mango orchard of $13,675 \mathrm{~m}^{2}$ and the other a garden comprising different production systems that covered $10,190 \mathrm{~m}^{2}$ (with an organopónico of over 3,765 $\mathrm{m}^{2}$ ) (Fig. 5).

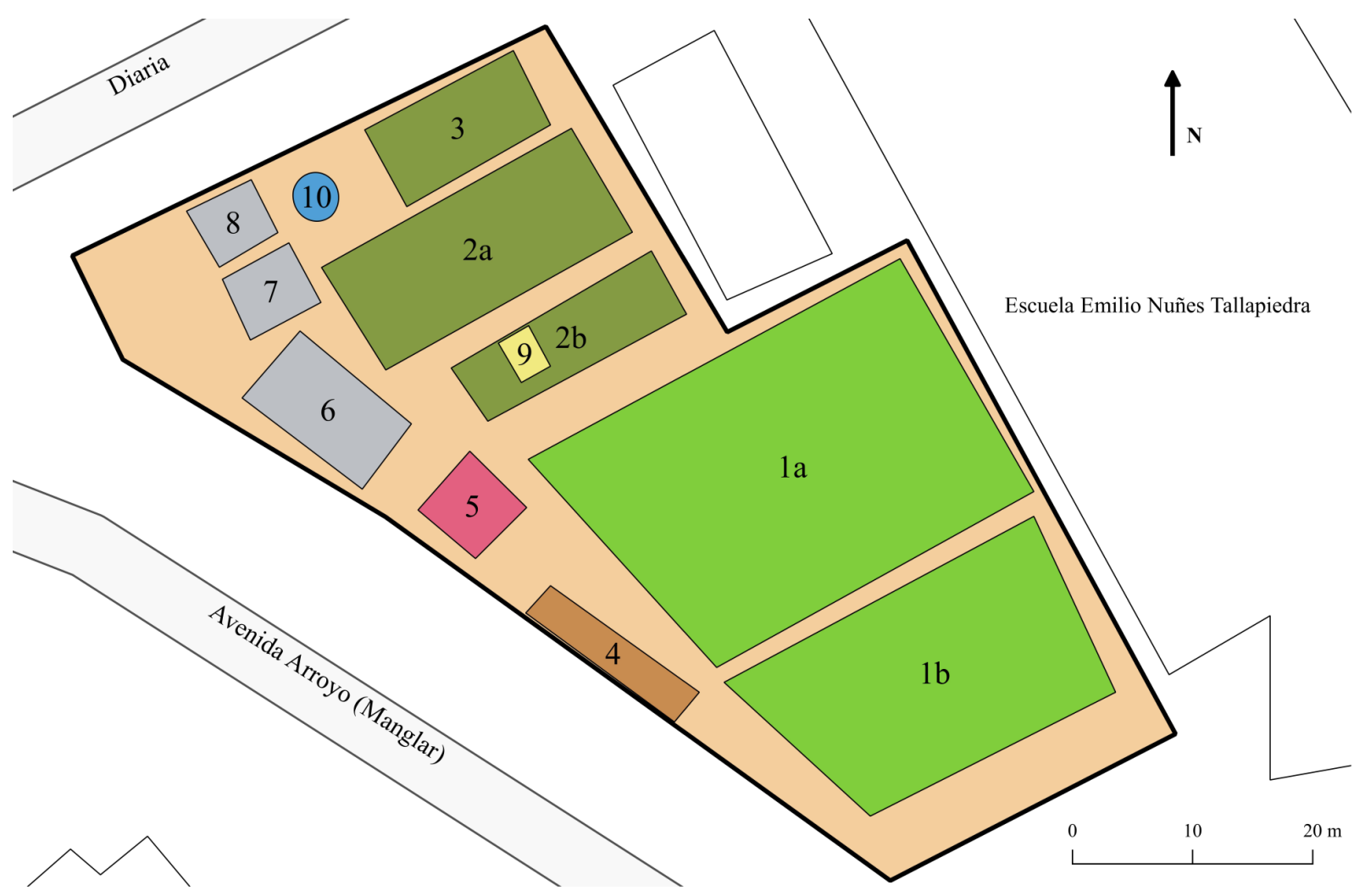

$1 \mathrm{a}, \mathrm{b}$ - cultivation in the ground; $2 \mathrm{a}, \mathrm{b}$ - ornamental plants and herbs; 3 - semi-protected cultivation of ornamental plants; 4 - composter; 5 - animal cages; 6 - outbuilding; 7 - cafeteria, 8 - point of sale; 9 - seed nursery; 10 - acuaculture tank 
The garden differed significantly from the above-mentioned $L a$ Ceiba mainly in its cultivation methods and the destination of its produce. As indicated by the name, the plants (vegetables, herbs, and medicinal and ornamental plants) were cultivated in raised container beds, which had been constructed using fragments of corrugated asbestos sheets and arranged in two groups of parallel rows, covered with shade cloth (Fig. 4). The plot was multiple cropped and drip irrigation was used. According to the respondent, the garden also had goats, chickens, rabbits

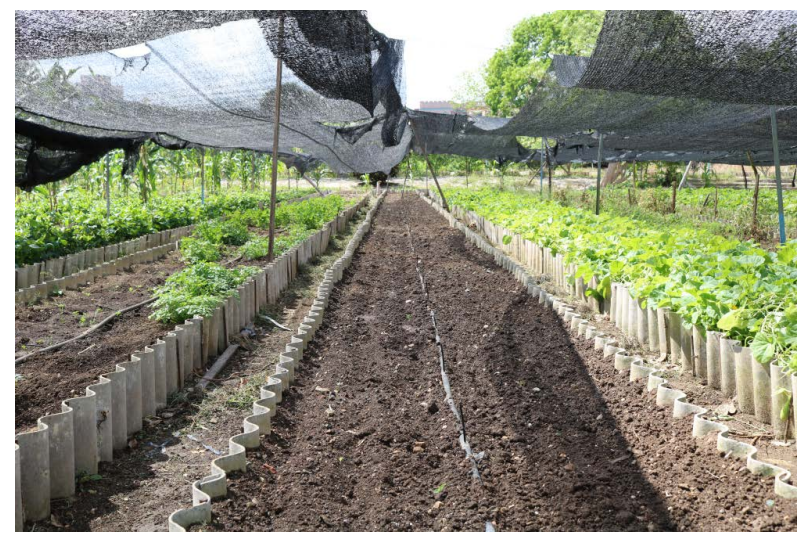

Figure 4. Semi-protected cultivation at Organopónico 'Santovenia' Source: photo taken by Krzysztof Górny and pigs. The compost was produced on site, as in the majority of the gardens visited. Although the site covered an extensive area it employed just two workers, which was an insufficient number according to the respondent. Unlike La Ceiba, everything produced here was destined for the 'Santovenia' Nursing Home. The garden offered no products to be made available to the public. It might be stated that the garden was not connected to the local food market, as the food produced was intended for the nursing home's own consumption needs only; instead, it constituted a small, closed food system in which production was directly connected to consumption. It also did not perform many additional functions other than food provision and employment.

\section{Conclusions and discussion}

Conclusions from this work are of both a cognitive and a methodological nature. The study, based on field observations and 21 semi-structured interviews conducted in 2018, provides accurate information on a sample of 43 urban gardens in the contiguously built-up areas of Havana. The average garden area was $7,512.44 \mathrm{~m}^{2}$. The most commonly grown plants were vegetables, such as lettuce, onions and spinach. The results of the research carried out attest to organopónico being the most common production technique applied within the research area. An important finding of the fieldwork was that the most common material used to construct the bordering walls of raised container beds was asbestos. The supposed role of the organoponic method in reducing the negative impacts of soil contamination on produced food might thus be compromised by the use of this material in the construction of the bordering

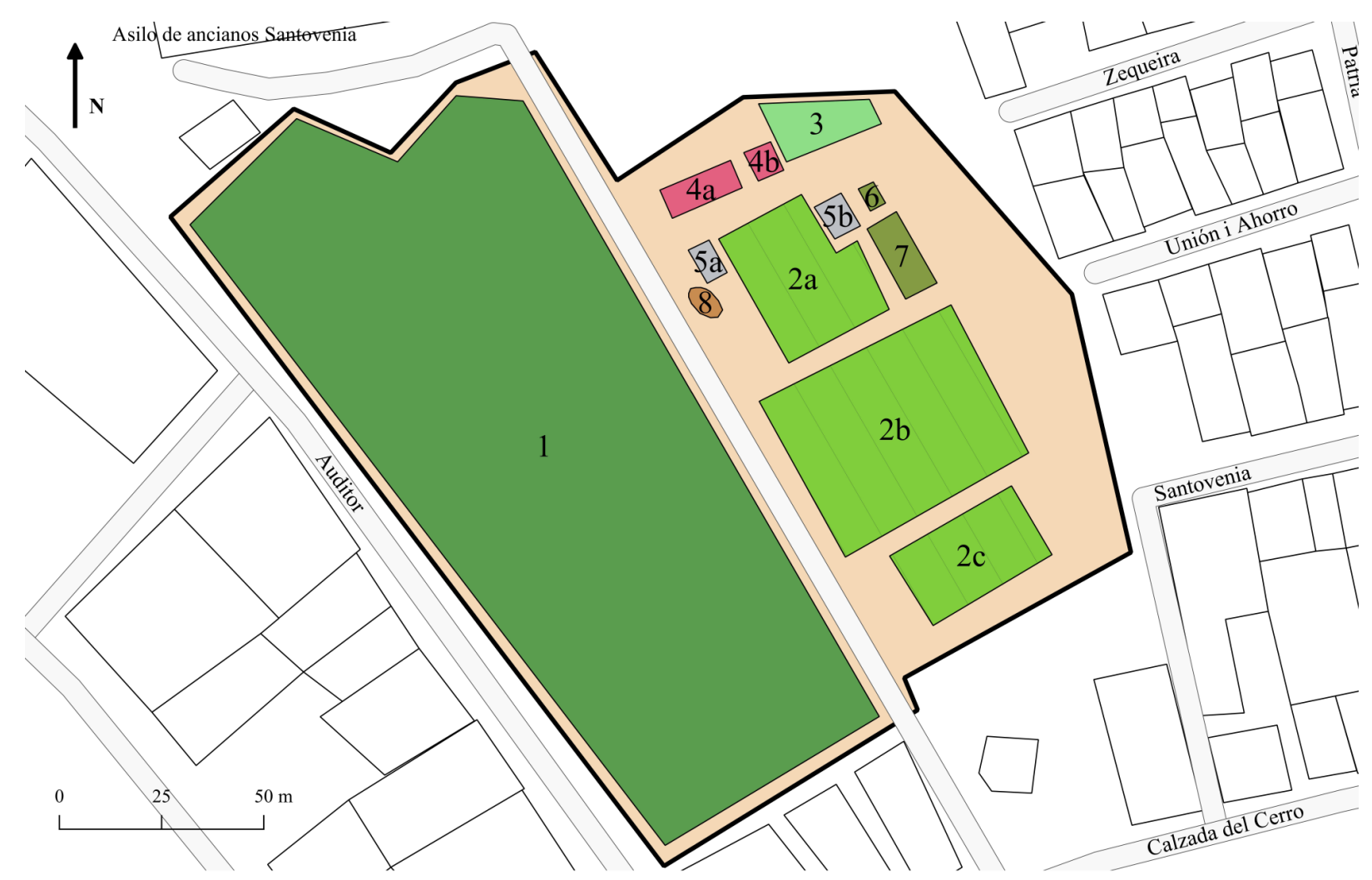

1 - mango orchard; $2 \mathrm{a}, \mathrm{b}$ and $\mathrm{c}$ - organoponic cultivation; 3 - fenced goats pasture; $4 \mathrm{a}, \mathrm{b}$ - animal enclosure; $5 \mathrm{a}$ and $\mathrm{b}$ - outbuildings; 6 - abandoned greenhouse; 7 - aloe cultivation in the ground; 8 - composter

Figure 5. Schema of Organopónico 'Santovenia'

Source: own elaboration on the basis of fieldwork undertaken in 2018 
walls, a material that may affect the health of both producers and consumers in a negative way. This therefore demonstrates the limitations of the application of organic production techniques in circumstances of restricted resources. Research to examine the impact of substances present in the walls of canteros, both in their construction and the ways they are used, would thus seem to be needed urgently.

Despite their strong institutionalized character, the urban gardens visited emerge as serving a commercial function also, as they contribute directly to the local food market. Produce from $43.2 \%$ of the surveyed sites was intended for sale. The two detailed case studies presented differed in terms of spatial organization, production methods used, functions performed, and above all the level of integration with the city's food provisioning system. All the produce that La Ceiba garden supplied was intended for sale, whereas in the case of Organopónico 'Santovenia' it was destined for the adjoining 'Santovenia' Nursing Home.

The spatial distribution of urban gardens present in the contiguously built-up areas of Havana reflects its urban history. Both colonial and modernist planning are visible in the contemporary urban space of Cuba's capital, and they have also exerted an indirect influence on where today's medium-size and large urban gardens are located. Urban agriculture is distributed across the city in an uneven fashion, the main concentration being in districts of lower-density urban construction, such as the environs of the Plaza de la Revolución. This reflects the availability of land resources intentionally left between buildings by modernist planners.

The research also shows the effectiveness of manual classification, achieved using Google Earth Pro satellite and aerial imagery, which indeed proved to be a suitable method by which to analyze the highly heterogeneous vegetation cover typical of urban gardens.

Hamilton et al. (2016) state in their review article that the extent of urban agriculture needs to be quantified more precisely, which could be achieved through far-reaching surveys and inventories. We also argue that comprehensive and systematic empirical research of both a quantitative and qualitative nature concerning spatial distribution, management and intrinsic features of gardens is essential to better understand the patterns of how urban agriculture in different cities of the world functions.

ORCID

Ada Górna (1) https://orcid.org/0000-0003-1591-7260

Krzysztof Górny (D) https://orcid.org/0000-0002-8088-3389

\section{References}

Altieri, MA, Companioni, N, Cañizares, K, Murphy, C, Rosset, P, Bourque, M \& Nicholls, Cl 1999, 'The greening of the "barrios": Urban agriculture for food security in Cuba', Agriculture and Human Values, vol. 16, no. 2, pp. 131-140.

Aubry, C, Ramamonjisoa, J, Dabat, MH, Rakotoarisoa, J, Rakotondraibe, J, Rabeharisoa, L 2012, 'Urban agriculture and land use in cities: An approach with the multi-functionality and sustainability concepts in the case of Antananarivo (Madagascar)', Land Use Policy, vol. 29, no. 2, pp. 429-439.

Buchmann, C 2009, 'Cuban home gardens and their role in social-ecological resilience', Human Ecology, vol. 37, no. 6, pp. 705-721.

Chaplowe, SG 1998, 'Havana's popular gardens: sustainable prospects for urban agriculture', Environmentalist, vol. 18, no. 1, pp. 47-57.

Clausen, R, Clark, B \& Longo, SB 2015, 'Metabolic rifts and restoration: Agricultural crises and the potential of Cuba's organic, socialist approach to food production', World Review of Political Economy, vol. 6, no. 1, pp. 4-32.

Cruz, MC \& Medina, RS 2003, Agriculture in the city: A key to sustainability in Havana, Cuba. Ian Randle Publishers.

De Bon, H, Parrot, L \& Moustier, P 2010, 'Sustainable urban agriculture in developing countries. A review', Agronomy for Sustainable Development, vol. 30, no. 1, pp. 21-32.

De Zeeuw, H, Van Veenhuizen, R \& Dubbeling, M 2011, 'The role of urban agriculture in building resilient cities in developing countries', The Journal of Agricultural Science, vol. 149, no. 1, pp. 153-163.

Díaz, JP \& Harris, P 2005, 'Urban agriculture in Havana: opportunities for the future' in CPULs. Continuous Productive Urban Landscapes: Designing Urban Agriculture for Sustainable Cities, ed. A Viljoen, Elsevier, Oxford, pp. 135-145.

Epelman, M 1993, 'The export of hazards to the third world: The case of asbestos in Latin America', NEW SOLUTIONS: A Journal of Environmental and Occupational Health Policy, vol. 2, no. 4, pp. 48-56.

Febles-González, JM, Tolón-Becerra, A, Lastra-Bravo, X \& Acosta-Valdés, X 2011, 'Cuban agricultural policy in the last
25 years. From conventional to organic agriculture', Land Use Policy, vol. 28, no. 4, pp. 723-735.

Forster, D, Buehler, Y \& Kellenberger, T 2009, 'Mapping urban and peri-urban agriculture using high spatial resolution satellite data', Journal of Applied Remote Sensing, vol. 3 , no. 1, pp. 1-12.

Górna, A 2018, 'Urban agriculture: an opportunity for sustainable development' in Globalización y desarrollo sostenible, eds. M Czerny \& CA Serna Mendoza, WUW, Warsaw, pp. 129-142.

Guitart, D, Pickering, C \& Byrne, J 2012, 'Past results and future directions in urban community gardens research', Urban forestry \& urban greening, vol. 11, no. 4, pp. 364-373.

Hallett, S, Hoagland, L, Toner, E, Gradziel, TM, Mitchell, CA \& Whipkey, AL 2016, 'Urban agriculture: Environmental, economic, and social perspectives', Horticultural Reviews, vol. 44 , pp. $65-120$

Hamilton, AJ, Burry, K, Mok, HF, Barker, SF, Grove, JR \& Williamson, VG 2014, 'Give peas a chance? Urban agriculture in developing countries. A review', Agronomy for sustainable development, vol. 34, no. 1, pp. 45-73.

Herrera Sorzano, A 2009, 'Impacto de la agricultura urbana en Cuba' [Impact of urban agriculture in Cuba], Novedades en Población [News in Population], vol. 5, no. 9, pp. 1-14.

Koont, S 2009, 'The urban agriculture of Havana', Monthly Review, vol. 60, no. 1, pp. 63-72.

Koont, S 2011, Sustainable urban agriculture in Cuba, University Press of Florida, Gianesville.

Leitgeb, F, Schneider, S \& Vogl, CR 2016, 'Increasing food sovereignty with urban agriculture in Cuba', Agriculture and human values, vol. 33, no. 2, pp. 415-426.

Mougeot, LJ 2000, Urban agriculture: Definition, presence, potentials and risks, and policy challenges. Cities feeding people series report 31, IDRC, Ottawa.

Murphy, C 1999, Cultivating Havana: urban agriculture and food security in the years of crisis. Development Report No12. Institute for Food and Development Policy, Oakland CA.

Nelson, E, Scott, S, Cukier, J \& Galán, ÁL 2009, 'Institutionalizing agroecology: successes and challenges in Cuba', Agriculture and Human Values, vol. 26 , no. 3, pp. 233-243. 
Novo, MG \& Murphy, C 2000, 'Urban agriculture in the city of Havana: A popular response to a crisis' in Growing cities, growing food. Urban agriculture on the policy agenda, eds. N Bakker, M Dubbeling, S Gündel, U Sabel-Koshella \& $\mathrm{H}$ de Zeeuw, ZEL, Feldafing, pp. 329-346.

Orsini, F, Kahane, R, Nono-Womdim, R \& Gianquinto, G 2013, 'Urban agriculture in the developing world: a review', Agronomy for sustainable development, vol. 33, no. 4, pp. 695-720.

Premat, A 2005, 'Moving between the plan and the ground: shifting perspectives on urban agriculture in Havana, Cuba' in Agropolis, ed. LJA Mougeot, IDRC, London, Sterling VA, Ottawa, pp. 171-204.

Premat, A 2009, 'State power, private plots and the greening of Havana's urban agriculture movement', City \& Society, vol. 21, no. 1, pp. 28-57.

Smit, J \& Nasr, J 1992, 'Urban agriculture for sustainable cities: using wastes and idle land and water bodies as resources', Environment and urbanization, vol. 4, no. 2, pp. $141-152$.

Smit, J, Nasr, J \& Ratta, A 2001, Urban agriculture: food, jobs and sustainable cities, 2nd ed, New York, USA.

Sroka, W 2014, 'Definicje oraz formy miejskiej agrokultury przyczynek do dyskusji' [Definitions and forms of urban agriculture - a contribution to the discussion], Wieś $i$ Rolnictwo [Countryside and Agriculture], vol. 164, no. 3, pp. 85-103.

Taylor, JR \& Lovell, ST 2012, 'Mapping public and private spaces of urban agriculture in Chicago through the analysis of highresolution aerial images in Google Earth', Landscape and Urban Planning, vol. 108, no. 1, pp. 57-70.

Tweedale, G \& McCulloch, J 2004, 'Chrysophiles versus chrysophobes: the white asbestos controversy, 1950s2004', Isis, vol. 95, no. 2, pp. 239-259.

UNFPA (United Nations Fund for Population Activities) 2007, State of the World's Population 2007: Unleashing the Potential of Urban Growth. United Nations Population Fund, New York. Available from: <https://www.unfpa.org/publications/stateworld-population-2007> [8 June 2019].

Van Veenhuizen, R 2014, Cities farming for the future: Urban agriculture for green and productive cities, IDRC, Silang, Ottawa.

Viljoen, A \& Howe, J 2005, 'Cuba: laboratory for urban agriculture' in CPULs. Continuous Productive Urban Landscapes: Designing Urban Agriculture for Sustainable Cities, ed. A Viljoen, Elsevier, Oxford, pp. 146-191.

Wright, J 2012, Sustainable agriculture and food security in an era of oil scarcity: lessons from Cuba. Routledge. 